\title{
Pirsonia guinardiae, gen. et spec. nov.: A parasitic flagellate on the marine diatom Guinardia flaccida with an unusual mode of food uptake*
}

\author{
E. Schnepf ${ }^{1}$, G. Drebes ${ }^{2} \&$ M. Elbrächter ${ }^{2}, * *$ \\ 1 Zellenlehre, Fakultät für Biologie, Universität Heidelberg; Im Neuenheimer Feld 230, \\ D-6900 Heidelberg, Federal Republic of Germany \\ ${ }^{2}$ Biologische Anstalt Helgoland, Wattenmeerstation Sylt; D-2282 List/Sylt, \\ Federal Republic of Germany
}

\begin{abstract}
Pirsonia guinardiae gen. et spec. nov. was discovered as a parasite on Guinardia flaccida in the North Sea near List/Sylt during a bloom of this centric planktonic diatom. It is a colourless, small flagellate with an oblique cell apex and two subapically inserting flagella of different length and different orientation. The flagellates attach to a host cell and form an antapical process which pierces the diatom frustule and develops inside into a "trophosome", consisting of a proximal digestion vacuole and distal pseudopodia which phagocytise host cytoplasm. The main body, the "auxosome", remains outside the host cell. The trophosome persists for some time after the detachment of the auxosome or its derivatives. There are two types of Pirsonia guinardiae. Type A attaches to the valvae as well as to the girdle region, the auxosome remains flagellated and generally detaches after the feeding process to divide twice (seldom 3 times). Thick-walled (resting?) cysts are formed. Occasionally, a fusion of two sister cells has been observed. Type B attaches only to the

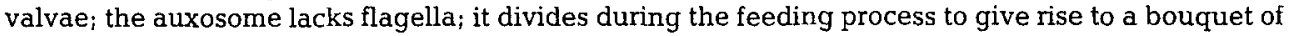
8 to more than 50 daughter cells which become flagellated when they detach. The taxonomical position of the flagellate is discussed. Diagnoses of genus and species are given.
\end{abstract}

\section{INTRODUCTION}

During routine weekly phytoplankton monitoring, in July 1989, a bloom of the centric planktonic diatom Guinardia flaccida was observed in the Wadden Sea near List/ Sylt (German Bight, North Sea). The population was heavily infected by a hitherto undescribed parasitic flagellate. As yet we cannot ascribe it to any of the known taxa.

We studied the structure and development of this flagellate and its mode of food uptake and observed an unusual pseudopodium- or haustorium-like antapical cell differentiation, the "trophosome", which performs phagocytosis and digestion. Lacking close similarities with other flagellates, a new genus, Pirsonia, was established, in honor of Prof. Dr. A. Pirson, Göttingen, and the species named Pirsonia guinardiae. Two types (type $A$ and $B$ ) are distinguished, each showing different development, and their relationship is discussed.

- Dedicated to Prof. Dr. A. Pirson on the occasion of his eightieth birthday.

* Mitglied der Taxonomischen Arbeitsgruppe an der Biologischen Anstalt Helgoland. 


\section{MATERIALS AND METHODS}

We used plankton samples, freshly collected from the Wadden Sea near List/Sylt, in addition to raw cultures of the host, Guinardia flaccida (Castr.) Peragallo (Centrales, Bacillariophyceae), and of the parasite. They were kept in Petri dishes in the Met medium described by Schöne \& Schöne (1982) at $16^{\circ} \mathrm{C}$ and under a 14:10 h light:dark regime. Subsequent to this study, clonal cultures of parasite and host could be established.

The parasite, together with infected host cells, was studied mainly in the living stage, in the Petri dishes, by means of sea-water immersion objectives (Leitz). The development was documented by flash light photographs and by means of a video recorder. The high sensitivity of the parasites, especially "Type B" cells, prevented an observation of the same cell over several hours. The documentation of the complete development of an individual cell was thus impossible. The figures are arranged with respect to the two types, not to the developmental stages. Each figure has the magnification $\times 1000$.

DNA was stained with DAPI.

We name the part of the parasite inside the diatom shell the "trophosome"; this part is specialized for food uptake and digestion. The nucleate part growing and dividing outside the diatom shell we name the "auxosome". Trophosome and auxosome form the trophontic phase, the "trophont", of the parasite.

\section{RESULTS}

\section{Infection rates}

In the first weeks of July 1989, Guinardia flaccida was the dominating plankton alga near the harbour of List as well as in the open sea. The temperature of the water initially ranged between $17^{\circ}$ and $19^{\circ} \mathrm{C}$, then dropped to $15^{\circ} \mathrm{C}$ without influencing the abundance of the algae and the parasites. On July 11, about 25000 cells per $\mathrm{dm}^{-3}$ were present of which at least $15 \%$ were infected with Pirsonia; by July 19 at least $30 \%$ of about 55000 cells per $\mathrm{dm}^{-3}$ were infected, whereas on July 28 the cell density of Guinardia had dropped to 2000 cells per $\mathrm{dm}^{-3}$ and about $20 \%$ were parasitized. Pirsonia had not been detected during routine plankton monitoring in the previous years.

The freshly collected material contained mainly the type $B$, whereas the type A was found only rarely. In raw cultures, the latter soon became apparent and then dominating, extinguishing the host within a few days. In contrast, type B did not readily develop in culture. All experiments, therefore, were carried out with type A.

\section{The flagellate stage}

The motile stage of the parasite consists of small, colourless flagellates which have the same structure in both type A (Figs 1-5) and type B (Fig. 44). They are variable in

Figs 1-7. Pirsonia guinardiae, type A, on Guinardia flaccida, $\times 1000$. Scale bar $10 \mu \mathrm{m}$. Fig. 1. Freeswimming flagellate with shorter anterior (right) and longer posterior flagellum (left). Figs 2 and 3. Flagellate swimming along a host cell, two consecutive micrographs, flagella partly out of focus. Figs 4, 5 and 6. Attachment of a flagellate, intervals of about $20 \mathrm{sec}$ between the single micrographs. Fig. 7. Many young trophonts in the girdle region of a single host cell, valvar view 

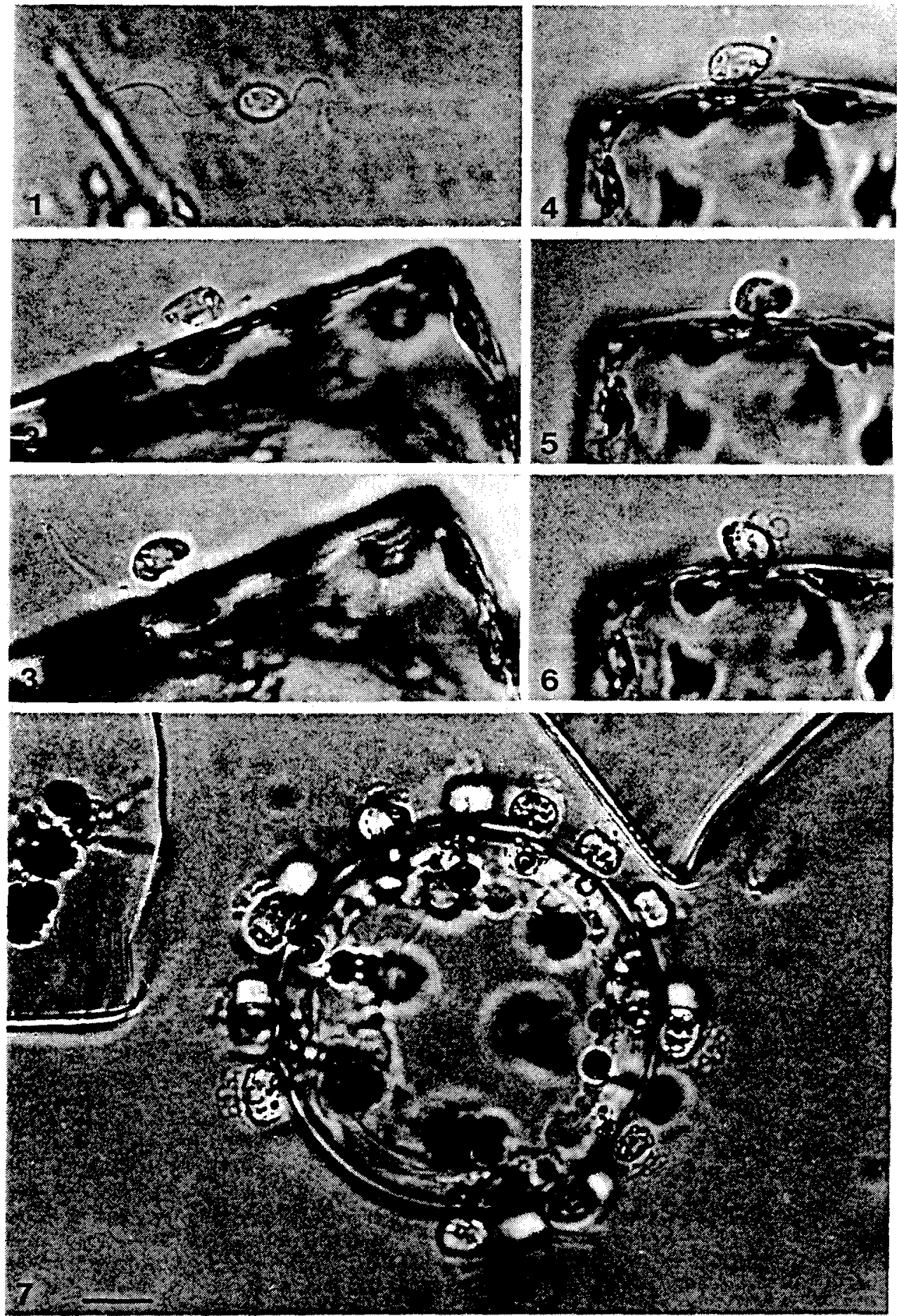
shape and size, generally elongate and laterally slightly flattened with a length of $7-12 \mu \mathrm{m}$ and a width of $5-7 \mu \mathrm{m}$. The ovoid nucleus is eukaryotic and measures $4 \times 3 \mu \mathrm{m}$. The cells contain many refractive granules, mainly in the antapical region of the cell, but no vacuoles. The apical part of the cell is oblique; there are two flagella inserted subapically (see also Figs 8,10 ), close together near the nucleus. They differ in length and in orientation. The anterior flagellum measures about $15 \mu \mathrm{m}$, the other is about $25 \mu \mathrm{m}$ long and oriented backward (Fig. 1). The difference in length can also be seen during flagellar development (Fig. 43). The flagellates swim rapidly, generally in a quivering movement, and are able to change direction abruptly into reverse.

\section{Attachment}

The flagellates seem to be attracted chemotactically by the host cells. When vegetative Guinardia cells are put into a dish with flagellates that have been starved for some time, the flagellates approach a host cell within one minute, swimming with their flagellar side along the surface of the frustule (Figs 2,3). Within less than 5 min, the first cells attach their antapical pole to the diatom shell (Figs 4-6). The B type is found nearly exclusively on a valva (Figs 27-41), whereas A-type flagellates settle down both in the girdle region (e.g. Figs 7, 14-19) as well as on the valvae (Figs 8, 9, 12, 13). The flagella wind around the cell apex within $2 \mathrm{sec}$ (Figs 5, 6, see also Figs 7-12); they persist in typeA cells (Figs 18, 19) but are lacking in attached type-B cells (Fig. 27).

Some Guinardia cells seem to be more attractive for the parasites than others. Several type-B cells can be found upon a single valva (Figs 29, 30,39) even in plankton samples which were not heavily infected. When cultures with "hungry" flagellates are fed with only a few host cells, many (up to more than, 20) parasite cells attack a single Guinardia cell (Fig. 7).

In such raw cultures, but never in wild plankton, also Rhizosolenia delicatula Cleve was found covered with attached parasite cells of the A type (Fig. 46). In this case, only a few formed a small trophosome (see below) and developed further (Fig. 47).

\section{Infection}

Soon after attachment, the flagellate differentiates into the trophont. It forms an antapical process which pierces the diatom shell and becomes visible as a small knob-

Figs 8-17. Pirsonia guinardiae, type A, on Guinardia flaccida, $\times 1000$. Scale bar $10 \mu \mathrm{m}$. Fig. 8 . Flagellate attached to a valva just before penetration of host cell. Fig. 9. The valva has been pierced, the developing trophosome appears as knob-like structure (arrowhead). Fig. 10. Developing trophosome in the girdle region; pseudopodia on a plasmolysed, chloroplast-free region of the host protoplast (arrowhead). Fig. 11. Young infection stage, the small trophosome (arrowhead) pushes the host plasmalemma inward; valvar region. Note the stellate chloroplasts. Fig. 12. A small digestion vacuole, containing one chloroplast, within the trophosome; valvar region. Fig. 13. Later trophont stage, a phagocytotic vacuole (arrowhead) in the trophosome between the proximal digestion vacuole and the distal pseudopodia upon a plasmolysed, chloroplast-free area of the host protoplast; valvar region. Fig. 14. Accumulation of host cytoplasm around the trophosomes of two trophonts that have pierced the girdle region. Figs 15-17. Formation of a phagocytotic vesicle (arrowhead) and its incorporation into the digestion vacuole; girdle region 

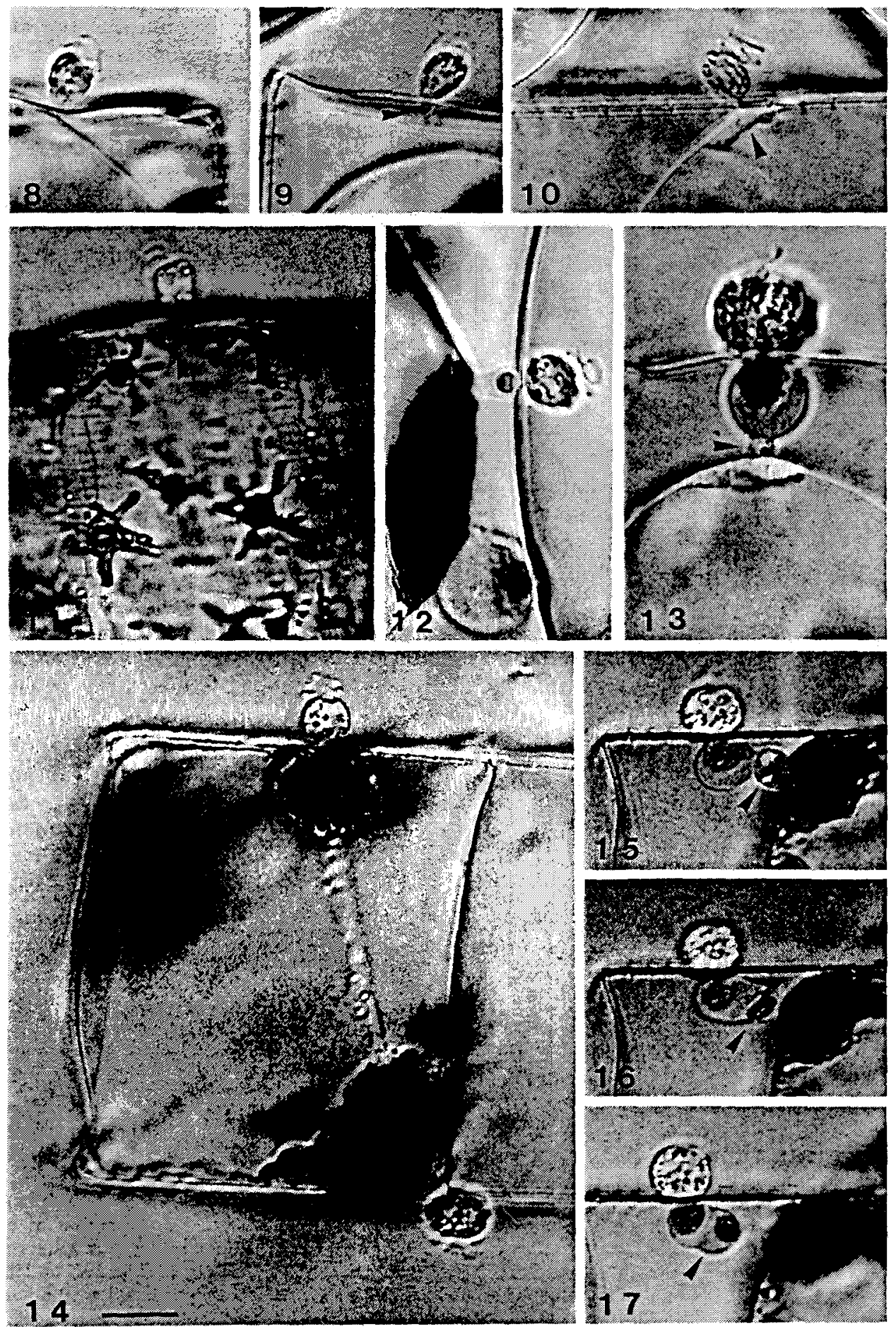
like structure in the interior of the host cell (Fig. 9) after about one hour. It contains some refractive granules typical of the parasite (Fig. 27) and pushes the protoplast of the host towards the interior of the cell (Fig. 11).

\section{Food ingestion and digestion}

The host cytoplasm reacts soon to the invasion. Cytoplasm and, especially, chloroplasts move along cytoplasmic strands toward the infection site as if they are attracted by the parasite (Figs 27-29). Later a bulk of cytoplasm, frequently together with the nucleus, concentrates near the invasion site(s) (Figs 14, 30-37). The chloroplasts, which are stellate in unattacked parts of the cell (Fig. 11), become spherical. The parasite's process inside the host frustule enlarges and differentiates into the "trophosome", consisting of an expanding "digestion vacuole" and some distally situated pseudopodia-like parts (Figs 10-13). The extravalvar main body of the trophont develops into the "auxosome" (see below). Since the accumulation of chloroplasts around a developing trophosome (see e.g. Fig. 14) hinders recognition of the further development in detail, the following data are based mainly on cells with multiple infections, which have less massive concentrations of host cytoplasm around the trophosome and often are plasmolysed.

Normally, i.e. in non-plasmolysed cells, there is a more or less narrow space between the trophosome and the locally displaced host plasmalemma (Figs 30, 32, 37, 40). Only at the distal cup of the globular part of the trophosome are the plasma membranes of host and parasite in close contact. The structural details of this contact area are visible only when the adjacent region of the host cytoplasm is chloroplast-free, as in plasmolysed cells. Then it becomes obvious that the distal part of the trophosome forms irregular, pseudopodium-like outgrowths which cover the host protoplast and penetrate into the latter (Figs 10,13). Here host and parasite are intimately indented and here is the site of phagocytosis. In plasmolysed host cells, the globular part of the trophosome with the digestion vacuole is connected with the phagocytising part through a cytoplasmic strand. The phagocytotic vesicles migrate through this strand from the site of phagocytosis to the digestion vacuole (Figs 12, 13, 15-17, 18, 40).

During phagocytosis, a portion of host cytoplasm becomes isolated from the protoplast and is included in a phagocytotic vesicle. Figures 15-17 show the formation of a phagocytotic vesicle and its fusion with the digestion vacuole in a plasmolysed A type infection; Figures 18 and 19 represent similar stages. In the A type, a relatively small phagocytotic vesicle fuses antapically with the digestion vacuole.

Figs 18-26. Pirsonia guinardiae attached to (Figs 18-20) or detached from Guinardia flaccida (Figs 21-26), $\times 1000$. Scale bar $10 \mu \mathrm{m}$. Fig. 18. Two host chloroplasts are phagocytised; girdle region. Note the flagella of the auxosome. Fig. 19. Nearly mature auxosome (note the flagella), phagocytosis of chloroplasts at the antapical pole of the trophosome; girdle region. Fig. 20. Trophosomes left after the detachment of the auxosomes. The arrowhead marks a previous connecting strand between auxosome and trophosome, passing the overlap between two intercalary bands. Surface view of the girdle region. Fig. 21. Cytokinesis of a detached auxosome. Fig. 22. The two offspring of an auxosome after the first division, interphase. Fig. 23. The two offspring of an auxosome, prophase of the second mitosis. Fig. 24. Second cytokinesis, note the tetrad-like configuration. Fig. 25. The four flagellates derived from one auxosome after the second division. Fig. 26. Eight flagellates derived from one auxosome 

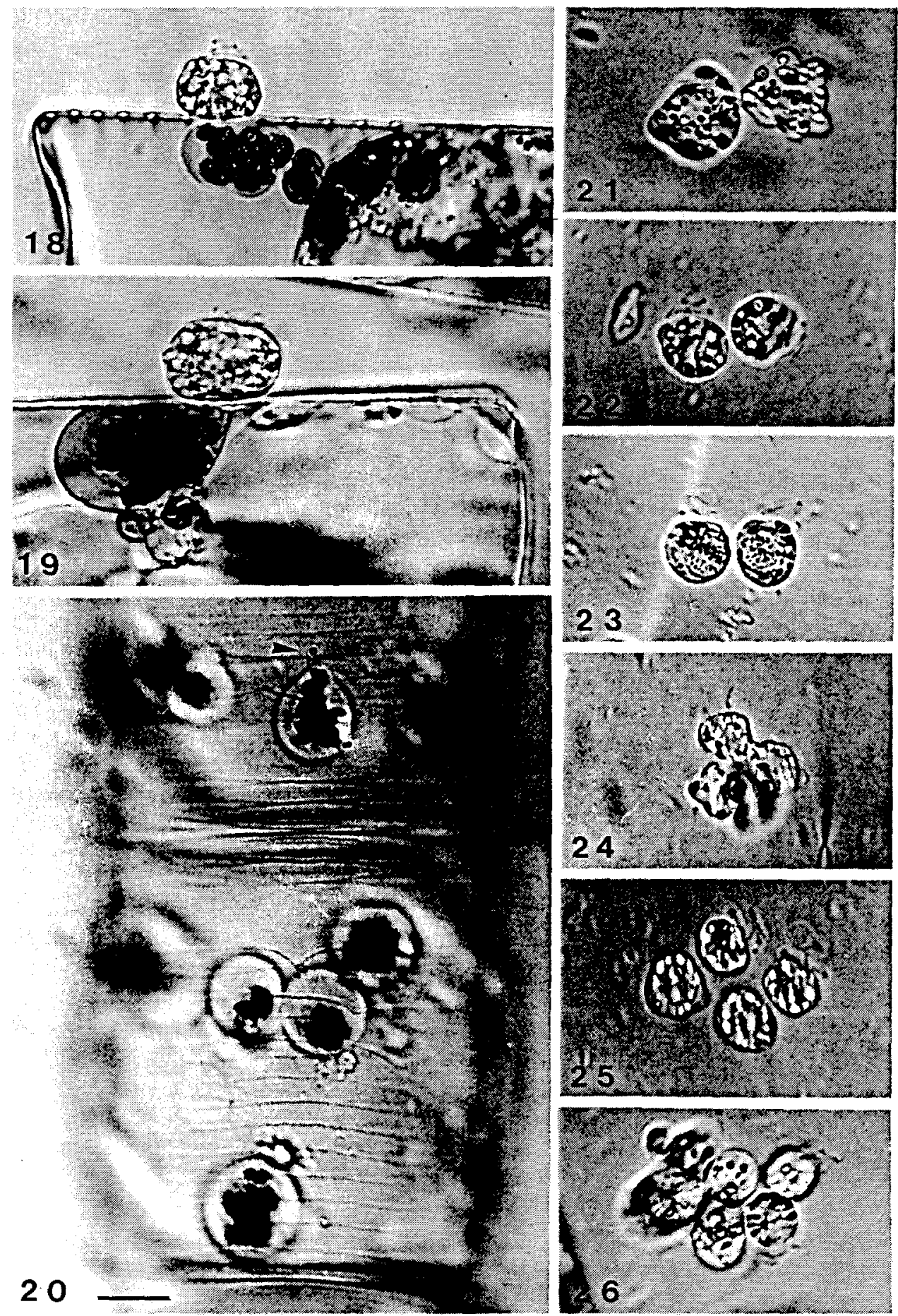
The phagocytotic vesicles of type-B parasite are generally larger and contain several (up to about 10) chloroplasts which become closely appressed to one another. The phagocytotic vesicles can reach a diameter of $12 \mu \mathrm{m}$ or more. Their development and migration are shown in Figures 32, 33 and 35-37. They become situated between the plasma membrane of the trophosome and the membrane of the digestion vacuole. As a consequence, the former bulges outward (Fig. 34), whereas the latter extends into the vacuole (Fig. 31). Trophosome and phagocytotic vesicle often form an aggregate like two soap bubbles attached to each other.

Only occasionally, and then again in chloroplast-free, plasmolysed host cell areas, some parasite cytoplasm can be seen to surround the phagocytotic vacuole (Fig. 40); generally, the two membranes which ensheath it (plasmalemma and vacuole membrane) are immediately adjacent to each other so that they cannot be resolved in profile view. The same is true for the border of the digestion vacuole and for the A type as well.

The phagocytotic vesicle moves from the distal end toward the proximal part of the trophosome (Figs 32, 33 and 35-37). Finally, its outer surface is fitted into the circumference of the trophosome and no longer bulges out. Thereafter, the phagocytotic vesicle fuses with the digestion vacuole. This process becomes visible by the changes in the appearance of the chloroplasts. They swell, change their colour, and disintegrate within about $3 \mathrm{~min}$. Later, they are transformed into an irregular, brownish residual body.

The time span of the whole process, from the separation of a portion of host cytoplasm to its entrance into the digestion vacuole, varies considerably. It takes a few minutes when only a small droplet of cytoplasm without chloroplasts is ingested, but some $15 \mathrm{~min}$ when the portion is very big. Continuous illumination impairs the uptake process. In the B type, usually about 5 big portions of host cytoplasm are taken up and digested. Due to the differences in development (see below), fully grown trophosomes of the A type have a rather uniform size (about $15 \mu \mathrm{m}$ in diameter) whereas those of the $\mathrm{B}$ type may reach $35 \mu \mathrm{m}$. Initially the portions of chloroplast remnants differ in color and structure (Fig. 34). Finally, only a single, brown, dense mass is left behind, the residual body (Fig. 39). The pseudopodial parts of the trophosome are withdrawn at the end of the feeding period. During the whole feeding process there is no vacuole visible in the auxosome.

Pirsonia has a unique way of defecation. The remaining trophosome with the digestion vacuole and the residual body persists for a short time when the development of the auxosome has been completed (see below) and the latter has detached from the host cell (Figs 20,39). Occasionally, it is then possible to recognize the small connecting strand between trophosome and auxosome and to see that it passes the overlap between two intercalary bands of the diatom shell (Fig. 20).

Figs 27-31. Pirsonia guinardiae, type B, on valvae of Guinardia flaccida, $\times 1000$. Scale bar $10 \mu \mathrm{m}$. Fig. 27. Young infection stage with tiny pseudopodium (arrowhead). Fig. 28. Disintegration of the first ingested chloroplasts (arrowhead) within the digestion vacuole. Fig. 29. The first ingested chloroplasts have been disintegrated; a group of other chloroplasts begins to be included in a phagocytotic vesicle (arrow); arrowhead: border of the trophosome. Fig. 30. A divided and further dividing (left) and a not yet divided (right) auxosome. The left trophosome contains a big phagocytotic vesicle (arrowhead), the right auxosome is in close lateral contact with the invaginated plasma membrane of the host cell (arrow). Fig. 31. Trophosome with a big, bulging phagocytotic vesicle, filled with chloroplasts 

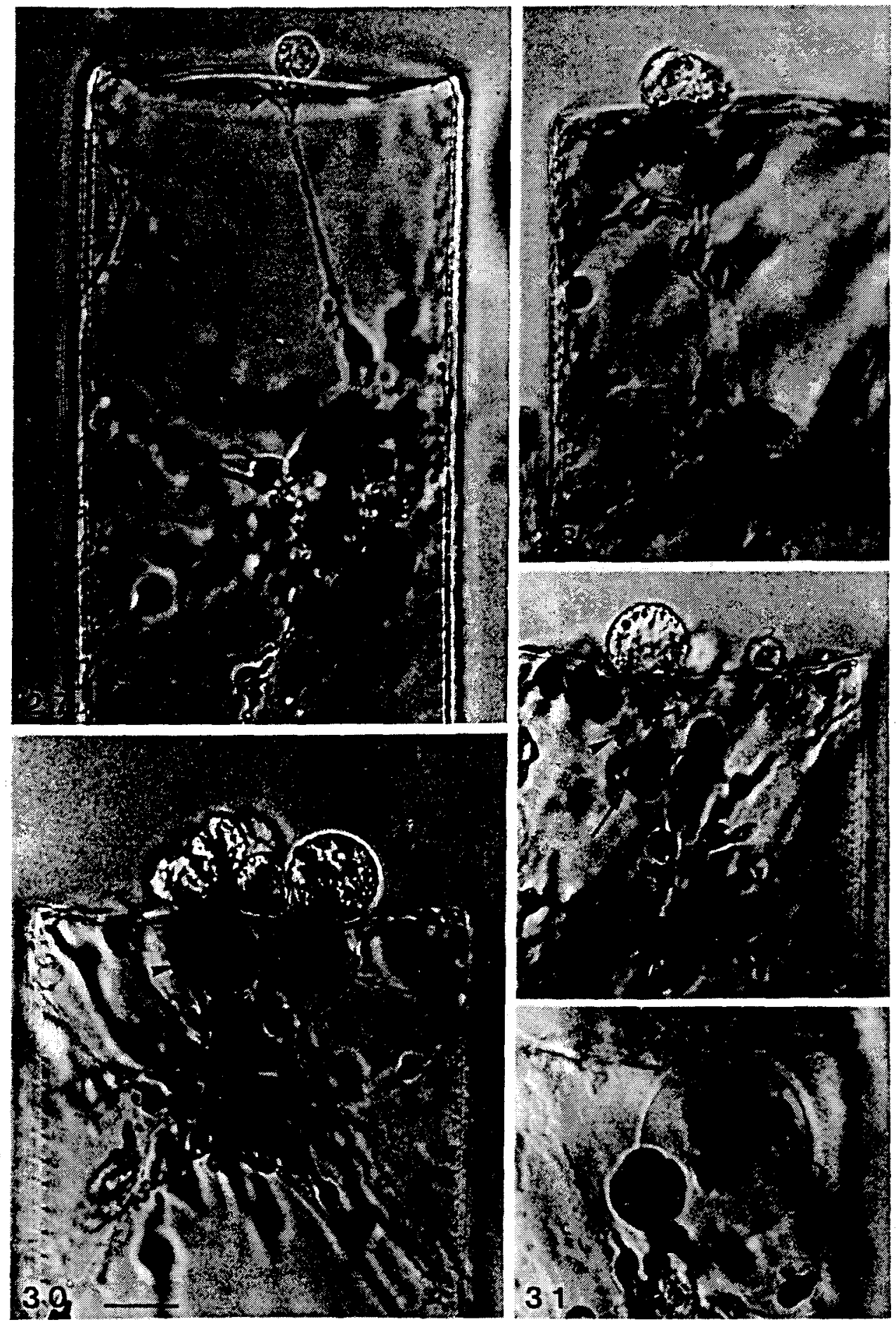
The host cell protoplast "deplasmolyses" and recovers when the membranes of the trophosome disintegrate. The residual body is then included between the plasmalemma and the frustuie (Fig. 38) and remains there even after the division of the cell.

A host cell may survive the attack of a single parasite, because the nucleus is generally not ingested (Fig. 40). In plankton samples only about one third of the infected cells were killed. In heavily infected cells, the cytoplasm is consumed nearly completely (Figs 20,39), frequently with the exception of the central vacuole which is filled with refractive reserve substances.

\section{Development of the auxosome}

The development of the type-A parasite differs considerably from that of the B type. Type-A flagellates attach in the girdle band region but also on the valvae. They retain the flagella which become wound around the cell apex in the very moment of attachment (Figs 4-6) and then remain non-motile. During the feeding process the auxosome becomes thicker (Figs 17-19), finally assuming the shape of a big apple with a diameter of $12-18 \mu \mathrm{m}$. The flagella insert in an apical depression. Generally, these cells do not divide as long as they are attached to the host cell.

When the digestion process is finished, the flagella become motile again. The auxosome detaches and swims away, but slowly and only for a short distance. It then settles down, remaining flagellate, undergoes mitosis and divides (Fig. 21). Usually, there are two subsequent divisions (Figs 22-25) within one hour. As a result a tetrad of daughter cells is formed (Fig. 24), indicating that the division planes change their direction. Occasionally, a third division follows (Fig. 26). The new flagella are formed during division.

Mitotic nuclei are conspicuously globular, clearly delimited against the cytoplasm and contain well discernible chromosomes (Fig. 23). The dividing cells are more or less globular (Figs 22, 23) but become irregularly ameboid-like in shape during cytokinesis (Figs 21, 24).

In two cases, we observed two cells of a tetrad remaining close together. About $10 \mathrm{~min}$ after the last division, they became amoeboid and fused (not shown). The "zygote"-like cell became motile $20 \mathrm{~min}$ after the fusion.

As it was possible to experiment with type-A cells in culture, data on the lengths of the single developmental steps (at $16-20^{\circ} \mathrm{C}$ ) can be given. The "hungry" flagellates were attracted within one minute and attached about $5 \mathrm{~min}$ after being fed with host cells (time zero). Then it took about $1 \mathrm{~h}$ for the trophosome to become clearly visible and $3-5 \mathrm{~h}$ to complete the feeding process. A maturation phase followed. The first cells detached $8-10 \mathrm{~h}$ after zero. The first tetrads were observed $10-13 \mathrm{~h}$ after zero and it took $16-20 \mathrm{~h}$ until new infections were observed.

Figs 32-37. Pirsonia guinardiae, type B, on valvae of Guinardia flaccida, $\times 1000$. Scale bar $10 \mu \mathrm{m}$. Figs 32 and 33. Two consecutive stages of formation and migration of a phagocytotic vesicle (arrowhead). Fig. 34. Bulging trophosome with a big phagocytotic vesicle (arrowhead) and two portions of chloroplast remnants within the digestion vacuole. Figs $35-37$. Migration of a big phagocytotic vesicle along the digestion vacuole (Figs 35, 36), and disintegration of its chloroplast after fusion with the latter (Fig.36): arrowhead; formation and migration of another, smaller 

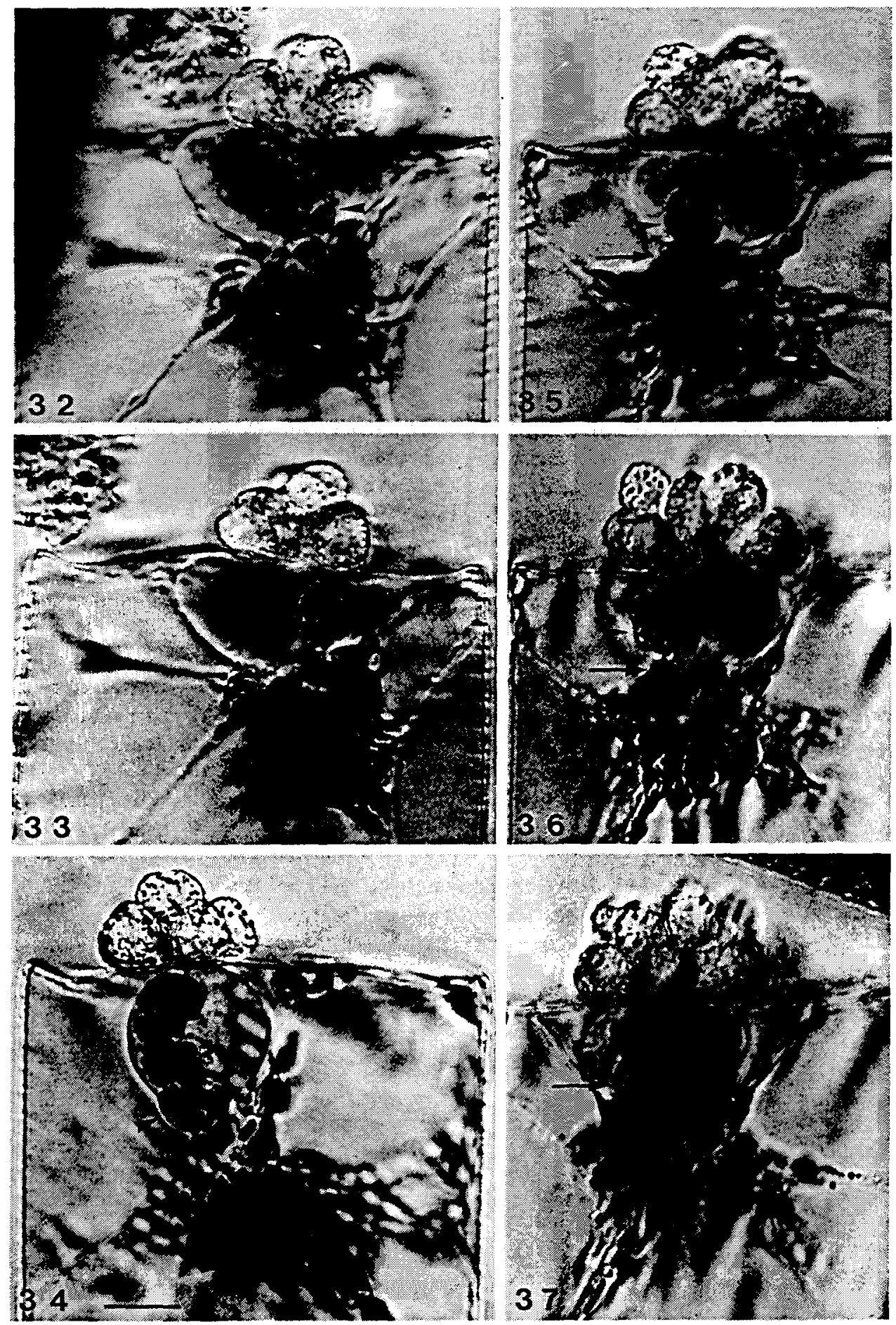
Flagellates of the B type attach only to the valvae of the host cell. Soon after settlement, the flagella are no longer visible. Because of the difficulties in culture we could not find out whether the flagellate withdraws or detaches. During the feeding process, the auxosome becomes thicker. It soon divides longitudinally, beginning from the apical pole (Fig. 30). Initially, the sister cells remain connected with the trophosome and continue to divide (Figs 32-37).

As a result, the $B$ type forms a bouquet-like group of oblong cells on the valva, consisting of 10-20, in some cases of more than 50 offspring (Figs 40, 41). The final divisions and developmental processes are not synchronous. While the first, generally laterally situated, cells become separated from the trophosome and begin to differentiate into flagellates, other cells continue to grow and to divide.

During the final differentiation, which takes about one hour, the cells assume the normal shape of the flagellate stage and develop flagella (Figs 40,41). The flagellates may detach from the bouquet even when their differentiation has not yet been completed, especially when there is a big group of offspring. In Figure 42, a group of globular offspring is shown which have become free even before the last division. The flagella will develop when this division has taken place and the daughter cells have not yet assumed the elongate shape; the unequal length of the flagella is seen in very young stages too (Fig. 43). It cannot be excluded that this irregularity is a consequence of a longer illumination during the observation under the microscope.

Auxosomes of the A and the B type can easily be distinguished by the presence or absence of the flagella as well as by the other differences mentioned above. There are, however, intermediate forms. In plankton samples and in raw cultures we occasionally observed B-type like infections also in the girdle region and B-type like aggregates from which single cells may detach before the last division had occurred, as mentioned above. Rarely, A-type trophonts were observed, which divided while still attached to the host. Infections with A-type cells resulted exclusively from A-type offspring.

The question whether Pirsonia has a DNA-rich kinetoplast besides the nucleus was tackled with DAPI staining of trophonts of the A type. Only the nucleus reacted positively (not shown).

All the results described above are derived from observations on raw cultures. Later, we succeeded in establishing clonal cultures of parasite (type A) and host. They enabled us to note, additionally, the occurrence of thick-walled cysts (not figured). They develop in ageing cultures. There are globular cysts with a diameter of about $10 \mu \mathrm{m}$ and flattened ones which are closely appressed onto the bottom of the Petri dish. The cysts are crowded with refractive granules of reserve substance and have a conspicuously brownishcoloured wall. The flat cysts are, moreover, surrounded by a brown material.

Figs 38-40. Pirsonia guinardiae, type B, on valvae of Guinardia flaccida, $\times 1000$. Scale bar $10 \mu \mathrm{m}$. Fig. 38. Recovered host cell, residual body between host plasmalemma and valva (right). Fig. 39. Multiple infection, one complete trophont (below), one left trophosome after auxosome detachment (middle) and one residual body liberated by the disintegration of the phagosome (above). Fig. 40. Nearly mature trophont; the offspring begin to form flagella; the trophosome has invaginated the host plasmalemma (double arrowhead); a small phagocytotic vesicle (arrowheads: its membrane) surrounded by some parasite cytoplasm attached to the digestion vacuole; the host cell is deprived of ${ }^{\text {- }}$ the chloroplasts (arrow: host cell nucleus) 

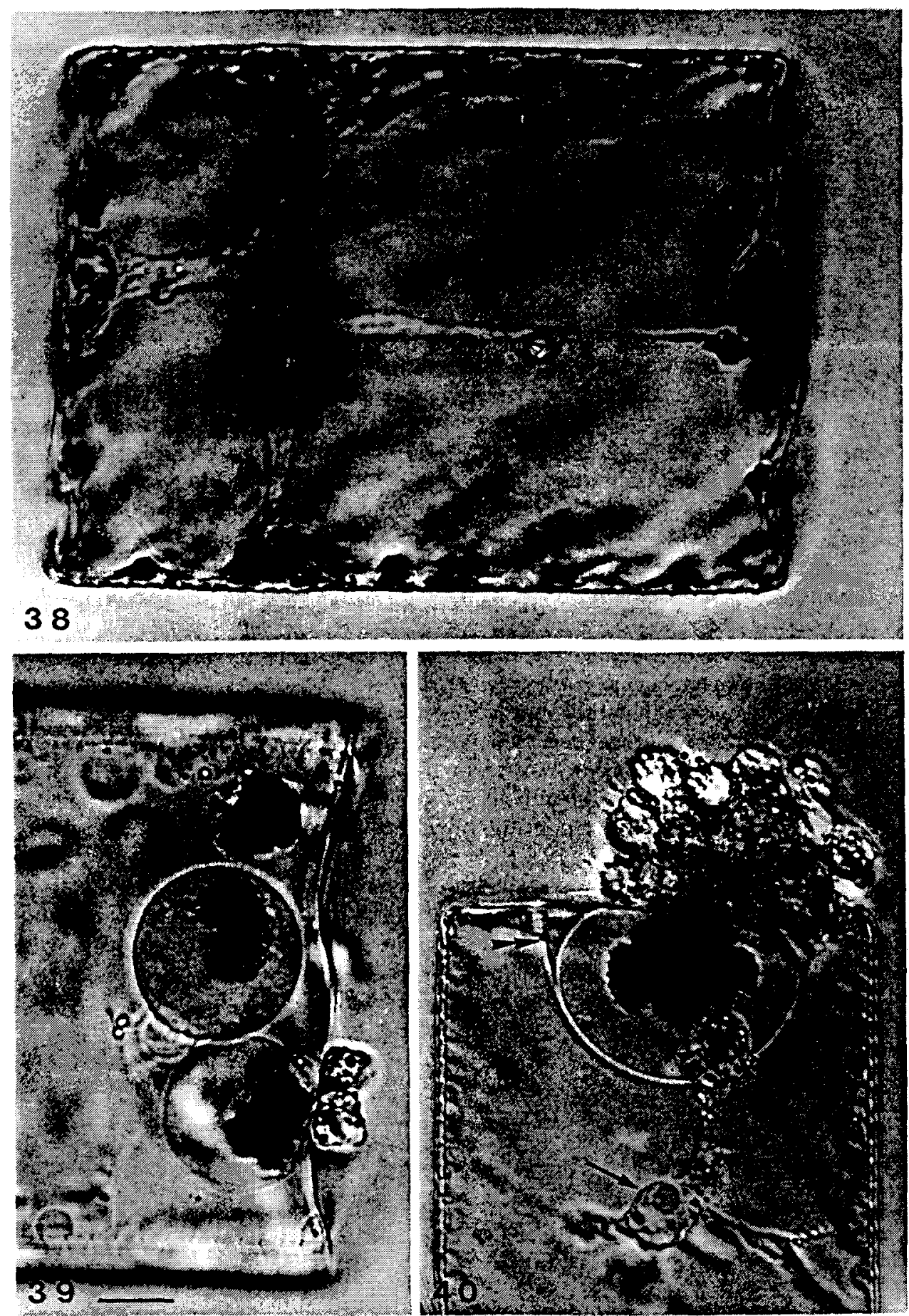


\section{DISCUSSION}

Flagellates which take up particulate food ingest it generally through a cytostome which is situated near the flagellar bases, or by pseudopodia which can be formed over the whole cell surface. To our knowledge, the occurrence of an uptake "organelle" like the "trophosome" of Pirsonia has never been described previously. Food uptake of Palisporomonas apodinium De Saedeleer, a parasitic flagellate which feeds on marine diatoms, seems to be similar in some respect though the description of the process (De Saedeleer, 1946) does not show this (see below). Our observations are thus of interest in regard to cell biology but may have taxonomical implications as well.

\section{Food uptake}

Some protists have special feeding structures; examples are the Suctoria or the Heliozoa with their axopodia. Especially diverse are the food uptake structures of phagotrophic and/or parasitic dinoflagellates, "peduncles" in Oodinium Chatton (Cachon \& Cachon, 1971), "rhizoids" (Lom \& Lawler, 1973), "feeding tubes" as, for example, in Paulsenella Chatton (Schnepf et al., 1985), or the "palliums" (see also the review of Gaines \& Elbrächter, 1987). Especially interesting is that Schizochytriodinium Elbrächter forms a "holdfast and sucking organelle" which consists essentially of a vesicular structure within the host protoplast, as in Pirsonia. It serves to ingest food which then, however, is digested in vacuoles within the main body of the parasite (Elbrächter, 1988).

The trophosome of Pirsonia develops like a pseudopodium. It pierces the shell of the host cell and then phagocytises host cytoplasm. In contrast to a true pseudopodium, it is only partly retracted when the feeding process has been finished. The digestion vacuole with the surrounding plasma and the plasma membrane is then severed from the auxosome. It does not represent a haustorium because it is not covered by a cell wall and does not take up nutrients in a soluble form but phagocytises. To emphasize its uniqueness, we named the specialised part of the parasite inside the diatom cell the "trophosome".

The elaboration of a structure like the trophosome is an adaptation to parasitic life and to the peculiarities of the host cell. It is presumably due to the existence of the diatom frustule and the constraints in connection with the development of the parasite which takes place outside the shell and thus allows the offspring to move away easily. The solution of these problems is to phagocytise and to digest food particles essentially

Figs 41-47. Pirsonia guinardiae, $\times 1000$. Scale bar $10 \mu \mathrm{m}$. Fig. 41. Mature type $B$ trophont at the valva of Guinardia flaccida, offspring with nearly full-length flagella. Fig. 42. Premature detached offspring, type B, four cells before division, one dividing (arrowhead) and one divided (arrow) cell pair. Fig. 43. Premature detached offspring, type B, formation of the flagella. Note the unequal length of the developing flagella (arrowhead). Fig. 44. Nearly mature flagellates, type B. Fig. 45. Offspring of the A type at the girdle region of a host cell, forming an unusual cell aggregate. Fig. 46. Flagellates of the A type attached to a Rhizosolenia delicatula cell. Fig. 47. Trophont (A type) on a Rhizosolenia delicatula cell; the trophosome (arrowhead) is surrounded by chloroplasts 

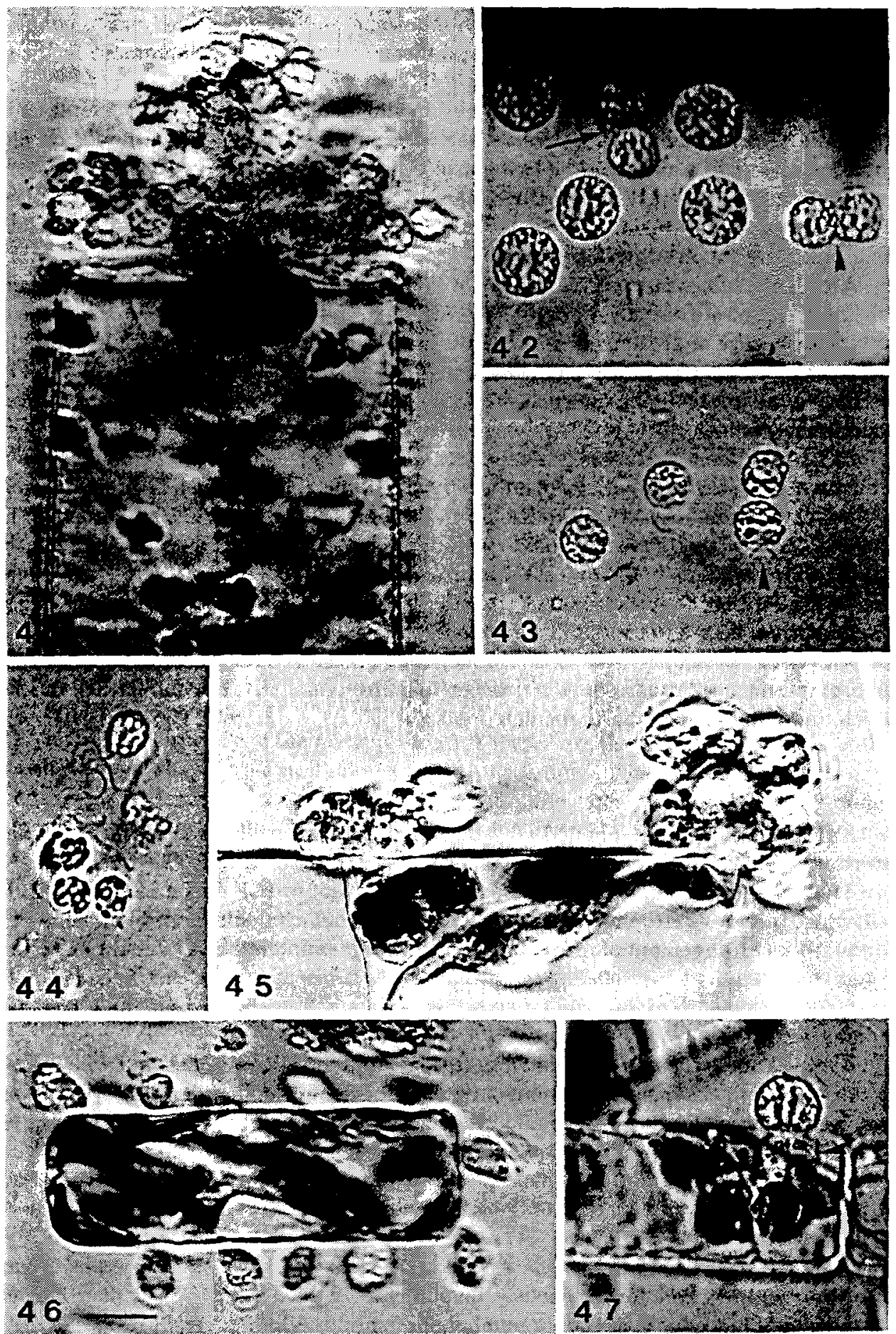
outside the main body, to differentiate a trophosome and an auxosome and to connect both by a tiny cytoplasmic connection strand through which only disintegrated food can pass.

This unique mode of nutrition is favoured by the tendency of the diatom cytoplasm to aggregate. The invasion of the parasite seems to imitate a signal which under normal conditions leads to a systrophe of cytoplasm around the nucleus. In consequence it is transferred toward the invasion site, by means of the host cell's own transport machinery, often even together with the nucleus. One can assume that disturbances of the ionic distribution are involved in this process.

A cell of Guinardia flaccida is only weakly silicified. This obviously enables the parasite to penetrate directly through the valva. It has only a single labiate process which, however, because of its shape is not suited to serve as an entrance (see Hasle, 1975). The occurrence of multiple infections at one valva likewise indicates that the shell is really pierced. In the girdle region the space between the overlapping cingula seems to be used to penetrate the cell.

Palisporomonas apodinium is a flagellate which likewise remains outside the diatom shell but penetrates it through its openings by an antapical process (De Saedeleer, 1946). The host cytoplasm then concentrates around the invasion site, as in a cell attacked by Pirsonia. Then a "trophic sac" is said to be formed from the host cytoplasm. This seems to be a misinterpretation, or the process was incorrectly observed. In contrast to Pirsonia, the part of the Palisporomonas trophont which is outside the diatom cell (corresponding to the auxosome) is said to contain a food vacuole in its basal part but only "liquid" food is believed to be taken up (De Saedeleer, 1946). If this is true, a distinct separation between auxosome and trophosome does not occur in Palisporomonas, in contrast to Pirsonia, which, in addition, takes up particulate food.

\section{Taxonomy}

It remains as yet unexplained why the B type prefers mainly the valvar region for infection whereas the $A$ type is not specialized in this respect. The differences in development - retention of the flagella after attachment or not, detachment of a single cell which divides (in general) only twice after detachment, or development of a bouquet-like arrangement of many daughter cells remaining attached - could be further arguments to support the idea that the two types are two separate species. Because of the occasional occurrence of intermediate types we hesitate, however, to take the B type as a separate species.

It must also be remembered that a re-fusion of tetrad cells was observed which arose by the twofold division of the trophont of type $A$. These development steps may represent a meiosis with a subsequent zygote formation by the fusion of isogametes. If this proves true, the A type would be the diploid phase which itself runs through an infectious cycle. The $B$ type would then be the haploid phase, with a similar but not identical vegetative cycle. It is, moreover, not usual that the same ecological niche is occupied by two closely related species.

Further studies can perhaps clarify the relationship between the two types. In any case, the culture conditions obviously favour type $\mathrm{A}$. In nature, type $\mathrm{B}$ may become overwhelming because of its higher number of offspring. Additionally, the origin (sexual- 
ity involved?), function (resting cysts?) and fate of the thick-walled cysts have to be investigated.

To our knowledge, a parasitic flagellate with a similar special differentiation into trophosome and auxosome and a similar way of phagocytosis, digestion and defecation has never been described before. Dactyliosolen mediterraneus ( $\mathrm{H}$. Perag.) H. Perag, a diatom closely related to Guinardia flaccida, was frequently found to be covered with an e p i p hy tic flagellate, Solenicola setigera Pavillard (Pavillard, 1916; see also Lebour, 1930; Pavillard, 1931; Cupp, 1943), but the data on its occurrence (no report about attachment to Guinardia flaccida), shape, flagellation and color indicate that this epiphyte is quite different from the present parasite.

As mentioned above, there is a certain similarity between Pirsonia and Palisporomonas with respect to the structures formed for food uptake. The resemblance between both organisms is perhaps even closer than the description of De Saedeleer (1946) indicates. There are, however, many differences between the two organisms, not only in that Palisporomonas seems to contain a food vacuole in the main cell body and thus does not have the organization into trophosome and auxosome. Palisporomonas is described as having trophocytes with only one (but sometimes two) flagellum and the zoospores are likewise said to have one or two flagella (then of slightly inequal length). The flagella are inserted subapically, but both are oriented foreward. In contrast, Pirsonia has always two flagella of different length and of different orientation. The main distinction is the mode of cell division. In Palisporomonas the trophocyte divides distally to give rise to one or a few gonocytes. The gonocytes produce sporocytes by successive division ("palisporogenesis"). Trophocyte, gonocyte and sporocyte remain connected by cytoplasmic bridges for a longer time, forming cell chains. The sporocytes eventually transform into zoospores.

The unique structure of the present parasitic flagellate, the trophosome, the flagellation and the cell shape prompted us not only to erect a new species but also a new genus. There seems to be no closer relationship with other flagellates; the position of the genus thus remains undetermined as yet. A more extensive investigation of Palisporomonas has to show whether perhaps the similarities between the two parasites are greater than one can deduce at present from the data of De Saedeleer (1946). If so, one will have to consider whether Pirsonia is to be included, with uncertain position, in the Palisporomonadidae, a family erected by De Saedeleer (1946).

The kind of flagellation precludes a relationship of Pirsonia with bodonoid flagellates (Fott, 1971; Lee \& Hutner, 1985). The mode of swimming likewise resembles that of Pseudobodo tremulans (Grießmann, 1913). In this case, Pirsonia should have a kinetoplast which, however, could not be detected with DAPI staining. In addition, Bodo Ehrenberg ingests food by means of a cytostome near the flagellar bases and one of the flagella is a trailing one. The Cercomonadina (Lee, 1985) are likewise not very similar to Pirsonia.

In the Euglenophyceae, there are both freshwater and marine parasitic flagellates which have one flagellum pointing foreward and the other one directed backward (Michajlow, 1972, 1977; Drebes, 1974). There are, however, no indications that Pirsonia has a pellicle; on the contrary, the occasionally ameboid changes in cell shape are hardly possible in the presence of a rigid outer cell layer. The obvious lack of paramylum grains (see Michajlow, 1964), and the mode of food uptake are further differences between 
Pirsonia and euglenoid flagellates. Bouquet-like cell aggregates like those in the B type occur in Euglenophyceae, too (Michajlow, 1964). They are found, however, in various, not closely related groups of flagellates, e.g. also in the Chrysophyceae (Fott, 1971).

Cryptophyceae may have a similar flagellation, and when they lack a cytopharynx and trichocysts (Fott, 1971), they may somehow resemble Pirsonia.

Spiromonas Alexeieff, also a biflagellated parasite of unknown taxonomical position (Foissner \& Foissner, 1984), differs in its mode of attachment (at the apical pole) and by its way of nutrition.

Some parasitic dinoflagellates do not develop typical gymnodinoid swarmers nor do they always have typical dinokaryotic nuclei (see Cachon \& Cachon, 1987 for review). Nevertheless, neither the motile stage nor the eukaryotic nucleus give any hint that Pirsonia may belong to the dinoflagellates - a group in which parasitism is abundant.

It is, as yet, premature to give Pirsonia a definite taxonomical position.

\section{Diagnoses}

Diagnosis: Pirsonia Schnepf, Drebes \& Elbrächter, gen. nov.

Parasites of diatoms. Free-swimming stages are colourless, small flagellates, laterally flattened with oblique cell apex and two subapically inserted flagella, a long anteriorly oriented one and a very long posteriorly oriented one. The cytoplasm contains many refractive granules. The flagellate attaches to a host cell and becomes a trophont, differentiating into an auxosome and a trophosome. The trophosome is situated inside the diatom shell; it includes a digestion vacuole and has small pseudopodia which phagocytise host cytoplasm. The auxosome remains outside the frustule; it does not contain vacuoles. Auxosome and trophosome are connected by a thin cytoplasmic strand. The auxosome detaches and divides thereafter or divides still attached to the host cell, giving rise to many offspring. The trophosome persists a short time after the detachment of the auxosome or its derivatives. Mastigophora incertae sedis.

Type species: Pirsonia guinardiae Schnepf, Drebes \& Elbrächter spec. nov.

Diagnosis: Pirsonia guinardiae Schnepf, Drebes \& Elbrächter, sp. nov.

Structure as described for the genus. Flagellates laterally flattened, about $10 \mu \mathrm{m}$ long and $6 \mu \mathrm{m}$ wide. Auxosome remains flagellated. Mature auxosomes apple-shaped, about $15 \mu \mathrm{m}$ in diameter, generally detaching before division, giving rise to 4 (to 8) daughter cells which are infectious without a longer resting phase. Thick-walled cysts present. Host: the marine planktonic diatom Guinardia flaccida, the valvae and the girdle region are penetrated. Distribution: marine plankton. Type locality: North Sea, near List/Sylt.

Holotype: Figs 1-26.

There is a second cell type (Figs 27-44) which penetrates only the valvae. Auxosome without flagella, divides longitudinally to give rise to a bouquet of offspring which remain connected with the trophosome. They become flagellated when they detach.

Acknowledgement. We are grateful to $\mathrm{H}$. Halliger for technical assistance, to Prof. Dr. K. Hausmann for valuable advice, and to $G$. Deichgräber for reading the manuscript. 


\section{LITERATURE CITED}

Cachon, J. \& Cachon, M., 1971. Ultrastructure du genre Oodinium Chatton. Différenciations cellulaires en rapport avec la vie parasitaire. - Protistologica 4, 153-169.

Cachon, J. \& Cachon, M., 1987. Parasitic dinoflagellates: In: The biology of dinoflagellates. Ed. by F. J. R. Taylor. Blackwell, Oxford, 571-610.

Cupp, E. E., 1943. Marine plankton diatoms of the west coast of North America. - Bull. Scripps Inst. Oceanogr. (Tech. Ser.) 5, 1-237.

Drebes, G., 1974. Marines Phytoplankton. Thieme, Stuttgart, 186 pp.

Elbrächter, M., 1988. Life cycle of Schizochytriodinium calani nov. gen. nov. spec., a dinoflagellate parasitizing copepod eggs. - Helgoländer Meeresunters, 42, 593-599.

Foissner, W. \& Foissner, I., 1984. First record of an ectoparasitic flagellate on ciliates: An ultrastructural investigation of the morphology and the mode of attachment of Spiromonas gonderi nov. spec. (Zoomastigophora, Spiromonadinae) invading the pellicle of ciliates of the genus Colpoda (Ciliophora, Copodidae). - Protistologica 20,635-648.

Fott, B., 1971. Algenkunde. Fischer, Jena, 581 pp.

Gaines, G. \& Elbrächter, M., 1987. Heterotrophic nutrition. In: The biology of dinoflagellates. Ed. by F. J. R. Taylor. Blackwell, Oxford, 224-268.

Grießmann, K. 1913. Über marine Flagellaten. - Arch. Protistenk. 32, 51-78.

Hasle, G. R., 1975. Some living marine species of the diatom family Rhizosoleniaceae. - Nova Hedwigia (Beih.) 53, 99-140.

Lebour, M. V., 1930. The planktonic diatoms of northern seas. Ray Soc., London, 244 pp.

Lee, J. J. 1985. Order 2. Cercomonadina Vickermann. In: An illustrated guide to the protozoa. Ed, by J. J. Lee, S. H. Hutner \& E. C. Bovee. Soc. Protozool., Lawrence, Kansas, 117.

Lee, J. J. \& Hutner, S. H., 1985. Order 11. Kinetoplastida Honigberg, 1963, emend. Vickermann, 1976. In: An illustrated guide to the protozoa. Ed. by J. J. Lee, S. H. Hutner \& E. C. Bovee. Soc. Protozool., Lawrence, Kansas, 141-153.

Lom, J. \& Lawler, A. R., 1973. An ultrastructural study on the mode of attachment in dinoflagellates invading gills of Cyprinodontidae. - Protistologica 9, 293-301.

Michajlow, W., 1964. Astasia norvegica sp. n. (Flagellata), parasite of some species of Cyclopoidea (Copepoda) in Norway. - Acta parasit. pol. 12, 339-355.

Michajlow, W., 1972. Problems of evolution of parasitism in Euglenoidina (Flagellata) - parasites of Copepoda. - Acta parasit. pol. 20,1-34.

Michajlow, W., 1977. Key for identifying species of Euglenoidina - parasites of Copepoda. II. Parasites belonging to the family Peranemidae. - Bull. Acad. pol. Sci. (Sér. Sci. biol., Cl. II) 25, 101-106.

Pavillard, J., 1916. Flagellées epiphytiques nouveaux des Diatomées pélagiques. - C. r. Acad. Sci. Paris $163,65-68$.

Pavillard, J., 1931. Phytoplankton (Diatomées, Péridiniens). - Résuit. Camp. scient. Prince Albert I $82,1-203$.

Saedeleer, H. de, 1946. Palisporomonas apodinium n. g., n. sp., Flagellé parasite épibiotique de Diatomées marines, type de la famille des Palisporomonadidae nov, fam. Morphologie et palisporogénèse. - Annls Soc. r. zool. Belg. 57, 90-165.

Schnepf, E., Deichgräber, G. \& Drebes, G., 1985. Food uptake and the fine structure of the dinophyte Paulsenella sp., an ectoparasite of marine diatoms. - Protoplasma 124, 188-204.

Schöne, H. K. \& Schöne A., 1982. A weakly enriched sea-water medium for ecological studies on marine plankton algae, some examples of its application. - Botanica mar. 25, 117-122. 